УДК 620.193.8:620.3: 669...691

(C) 2016

\author{
Shavanova K., Candidate of Biological Sciences, \\ Starodub N., Candidate of Biological Sciences, \\ Taran M., postgraduate student
}

National University of Life and Environmental Sciences of Ukraine

\title{
BIOLOGICAL EFFECT OF SOME METAL OXIDES NANOCOMPOSITES ON SACCHAROMYCES CEREVISIAE
}

\section{Reviewer - Candidate of Agricultural Sciences N. Novyts'ka}

Досліджено вплив трьох типів наноструктурованих металовмісних сапонітових глин на життєздатність пивних дріжджів Saccharomyces cerevisiae. Eкспериментальні дані показують, щчо досліджувані матеріали, незважаючи на те, що вони мають частки нанометрового розміру, не проявляють інгібуючу дію на організми. У дослідженні продемонстровано значне збільшення кількості клітин для $S$. cerevisiaewas за дї наноматеріалів. Найбільша концентрація клітин була зареєстрована за дії нанокомпозиту Nb-Sap-EtO в кониентрачії 2 мг/мл, у иих умовах кількість клітин було збільшено до 5 разів у порівнянні з контролем. 3 а даними МTT тесту спостерігається стимулювання активності мітохондріальних редуктаз у пивних дріжджах за впливу наноматеріалів, які містять у своєму складі ніобій в концентраціях від 0,5 мг/мл.

Key words: brewer's yeast, nanoparticles, saponite, toxicity, cells, mitochondrial reductase.

Statement of the problem. Nanosized and nanostructured materials have a major potential for a practical application in a large number of research fields, in the industrial production as well as in everyday life. However, at the nanoscale level many substances acquire new properties and therefore may become biologically very active, interacting cooperatively or detrimentally with various biologic processes. It raises a series of issues about the potential toxic effects of nanomaterials on living organisms as a consequence of either intentional or unintentional contact with them. Thus, the assessment of the biological toxicity, if any, for any newly-obtained nanosized or nanostructured materials and nanocomposites is a key issue which has to be clarified before the full integration in everyday life.

Several reviews have already focused on the possible risks of the nanotech- and nanoscience-derived products [26], assessing potential hazards towards aquatic species, invertebrates, algae, plants and fungi [21, 14]. Moreover, there is an increasing number of experimental evidences indicating absorption of nanosized particles into cells and tissues [11], their translocation into non-target organs [18], and various adverse effects, such as inflammation, genotoxicity, teratogenesis and carcinogenesis $[16$, 17]. Among numerous nanostructured materials currently produced, metal and metal oxide nanoparticles are considered the most potentially dangerous because of their ability to breach epithelial barriers [13]. The negative effect of such nanosized materials may act at least in four different directions: i) by means of the nanoparticle or the nanosized material itself [7]; ii) by dissolution of the nanosized material with the consequent release of active ions from it [12]; iii) by a combined effect of the nanoparticle and of the released ions, both contributing to the toxicity [9], and iv) by a «Trojan Horse» effect, leading to an uncontrolled intake of possible hazardous impurities on/in the material [15]. Some uncertainty also exists on the role of nanostructured material size and shape in determining toxicity: in fact, while it is almost generally accepted that the biological activity increases as the particle size decreases, some studies reported contradictory results on this topic [28, 29]. Although for some nanoparticles the toxicity has been reported $[22,24]$, nevertheless too little is known about the mechanisms of such effects. The scientific literature on nanotoxicology consists of around 800 publications, generally about the cytotoxic effects of nanomaterials in cell culture system (in vitro). For instance, several recent papers point to the uptake and accumulation of nanosized materials in the prokaryotic and eukaryotic cells [20, $1,3,10,27]$ and their toxicity [8, 2, 4]. Cells of plants, algae, and fungi constitute a primary site for interaction and a barrier for the entrance of nanoparticles. Mechanisms allowing nanoparticles or nanosized crystallites to pass through cell walls and membranes are as yet poorly understood.

Goal of study. Our main goal was testing different nanostructured clay-based materials to evaluate their safety in the perspective of any further application in the field of the decontamination and abatement of chemical warfare agent. In the present study, we report the experimental data about the potential toxic effect of novel types of nanocomposites onto brewer's yeast $S$. cerevisiae cells. 
Materials and methods of research. Three types of nanocomposites based on the phyllosilicate clay saponite were examined at different concentrations: H-Sap is a protonic acid form of saponite, prepared according to the optimized procedure and reported previously [19]; Nb-Sap-EtO is a type of $\mathrm{Nb}$ containing saponite clay (composition: $(\mathrm{Na})_{0,81} \mathrm{Mg}_{6}(\mathrm{OH})_{4}\left(\mathrm{Al}_{0,81} \mathrm{Nb}_{0,07} \mathrm{Si}_{7,11}\right) \mathrm{O}_{20} \cdot \mathrm{nH}_{2} \mathrm{O}$ and a $\mathrm{H}_{2} \mathrm{O}: \mathrm{Si}$ ratio $\left.=20: 1\right)$, prepared by adapting and tuning a method offered in the literature for parent saponite systems [5]; Nb-Sap-Cl is a niobiumcontaining saponite. Later it was prepared as follows: 6,68 g of amorphous $\mathrm{SiO}_{2}(99,8 \%$, Aldrich 381268) were dispersed in $50 \mu \mathrm{l}$ of water containing $0,63 \mathrm{~g}$ of $\mathrm{NaOH}$. The obtained gel was stirred for $1 \mathrm{~h}$ at RT. $3,20 \mathrm{~g}$ of $\mathrm{Al}\left[\mathrm{OCH}\left(\mathrm{CH}_{3}\right)_{2}\right]_{3}(98 \%$, Aldrich 22041-8) and 24,86 $\mathrm{g}$ of $\mathrm{Mg}(\mathrm{AcO})_{2} \cdot 4 \mathrm{H}_{2} \mathrm{O}(99 \%$, Aldrich 22864) were added and the gel was stirred for further $4 \mathrm{~h}$. At the same time $0,37 \mathrm{~g}$ of $\mathrm{NbCl}_{5}$ $(99,5 \%$, Aldrich 215791) and 5,6 $\mathrm{g}$ of tetraethoxysilane (TEOS, $98 \%$, Aldrich 131903) were dissolved in $500 \mu \mathrm{l}$ of water. The final solution was added to the gel and stirred for $1 \mathrm{~h}$. Then the gel was poured in a Teflon cup of a sealed autoclave (Anton Parr 4748) and heated in an oven for $72 \mathrm{~h}$ at $240{ }^{\circ} \mathrm{C}$. After the hydrothermal crystallization the solids were filtered, washed with deionized water to neutrality and dried in an oven for $24 \mathrm{~h}$ at $100{ }^{\circ} \mathrm{C}$.

Scanning Electron Microscopy (SEM) was used to characterize the samples microstructure in a Leo 1550 Gemini SEM at operating voltage ranging from $10 \mathrm{kV}$ to $20 \mathrm{kV}$ and standard aperture value 30 $\mu \mathrm{m}$. The study of the biocidal effect of the nanostructured materials was performed using brewer's yeast $S$. cerevisiae. The bioassay was performed using the following procedures.

Yeasts cultivation. Pure culture of $S$. cerevisiae strain U-517 from the collection of the Institute of Microbiology and Virology of the National Academy of Sciences of Ukraine was cultivated on the yeast extract peptone dextrose (YPD) medium during 1 night at $28^{\circ} \mathrm{C}$. The daily cultures at a concentration of $10^{5}$ cells ml ${ }^{-1}$ in $25 \mathrm{ml}$ of YPD medium at the certain concentrations of nanomaterials $\left(0,5 \mathrm{mg} \mathrm{ml}^{-1}\right.$, $1,0 \mathrm{mg} \mathrm{ml}^{-1}, 1,5 \mathrm{mg} \mathrm{ml}^{-1}, 2,0 \mathrm{mg} \mathrm{ml}^{-1}$ ) were incubated for $24 \mathrm{~h}$. The number of cells have been counted in the Goryayev camera [6].

MTT assay. After daily processing of the cells by the materials to be tested, $100 \mu 1$ of yeast culture were incubated in the presence of $20 \mu 1$ of MTT (3(4,5-dimethylthiazol-2-yl)-2,5-diphenyltetrazolium bromide) at the concentration of $5 \mathrm{mg} \mathrm{ml}^{-1}$ during $3,5 \mathrm{~h}$ at $37^{\circ} \mathrm{C}$ in 96 -well plates. It was repeated three times as minimum. After incubation the culture medium was removed and formazan (3-(4,5dimethylthiazol-2-yl)-1,3-diphenylformazan) crystals dissolved in $150 \mu 1$ of DMSO. At last, the cells were incubated in the presence of DMSO in dark for 15 $\mathrm{min}$, after they were measured to determine optical density formazan at a wavelength of $620 \mathrm{~nm}$ [25].

Results and discussion. The microstructures of the clay samples studied by SEM are presented in picture 1. The H-Sap samples have a shape that reflects the tetragonal structure and at the dissolution they agglomerate into large domains remaining porous with a pore size of $100 \mathrm{~nm}$ that indicated a substantial area of the active surface. The Nb-Sap-EtO sample was in the form of platelets 20 to $30 \mathrm{~nm}$ thick. Nb-Sap-Cl aggregates had a size of $c a .30 \mathrm{~nm}$ and, as the previous ones, were able to coalesce with the formation of larger domains.

It has been observed that under the influence of the solid samples the number of $S$. cerevisiae cell increased significantly (Pic. 2).
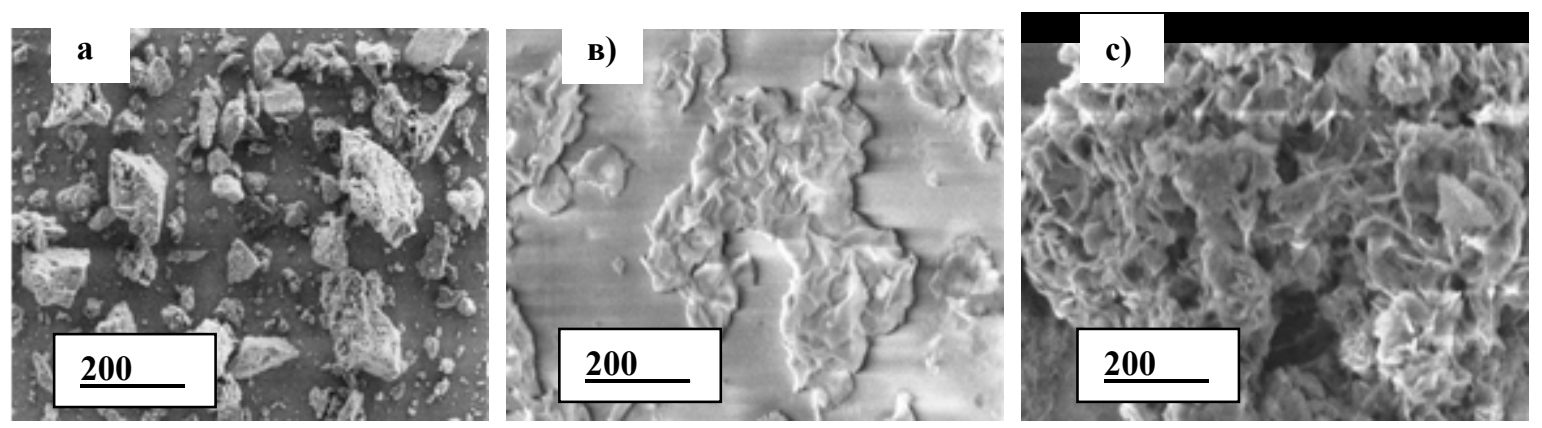

Pic. 1. SEM images of the nanocompositions: a) H-Sap, в) Nb-Sap-EtO, c) Nb-Sap-Cl 


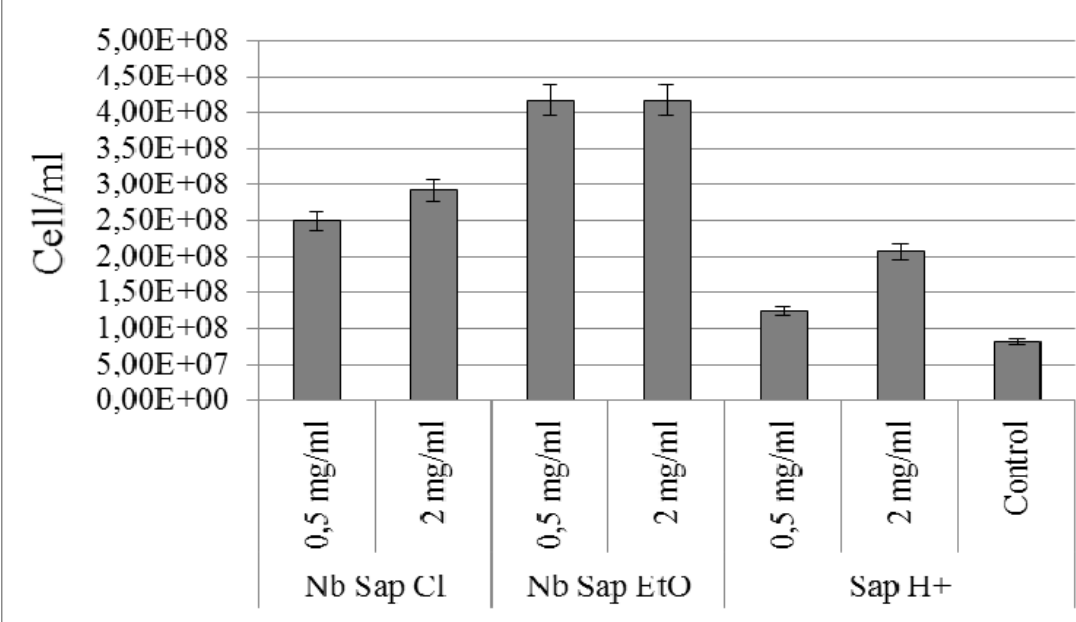

Concentrations of nanocomposites $\mathrm{mg} / \mathrm{ml}$

Pic. 2. Biological effect of saponite-based clays (H-Sap, Nb-Sap-EtO, and Nb-Sap-Cl) on the growth of $S$. cerevisiae cells number

The greatest effect is observed in the presence of $\mathrm{Nb}-$ Sap-EtO at a solid dispersion content of $2 \mathrm{mg}$ $\mathrm{ml}^{-1}$, where a cell concentration of $4,17 * 10^{8}$ cells ml $^{-1}$ was achieved, which corresponds to an almost 5fold increase in their numbers compared to the control.

This fact can be explained by the remarkable redox and acid-driven hydrolytic properties of niobium-containing saponites [23]. Such features have been successfully exploited for catalytic purposes. In these tests the Nb-containing clays (in particular Nb-Sap-EtO) were likely able to accelerate the digestion and degradation of micronutrient complexes into simpler compounds. Therefore, the absorption and assimilation of nutrients by the yeast could take place at a lower energy cost and it resulted to be faster and more efficient.

As far as the results of the MTT test are concerned (Pic. 3), the most pronounced effect compared with the control has been recorded for H-Sap and $\mathrm{Nb}-$ Sap-EtO, at a concentration of $0,5 \mathrm{mg} \mathrm{ml}^{-1}$ as well as for the $\mathrm{Nb}-\mathrm{Sap}-\mathrm{Cl}$ sample at a concentration of 2,0 mg ml $\mathrm{m}^{-1}$. In the presence of these clays the cell number was higher up to $c a$. 4 times with respect to the reference level. When H-Sap and Nb-Sap-EtO were added to the yeast cells in a concentration of $0,5 \mathrm{mg} \mathrm{ml}^{-1}$, the optical density were 0,7845 and 0,7852 respectively. Interestingly, by increasing the concentration of the clays in the culture medium, the effect was slightly smaller, but still greater than the control.

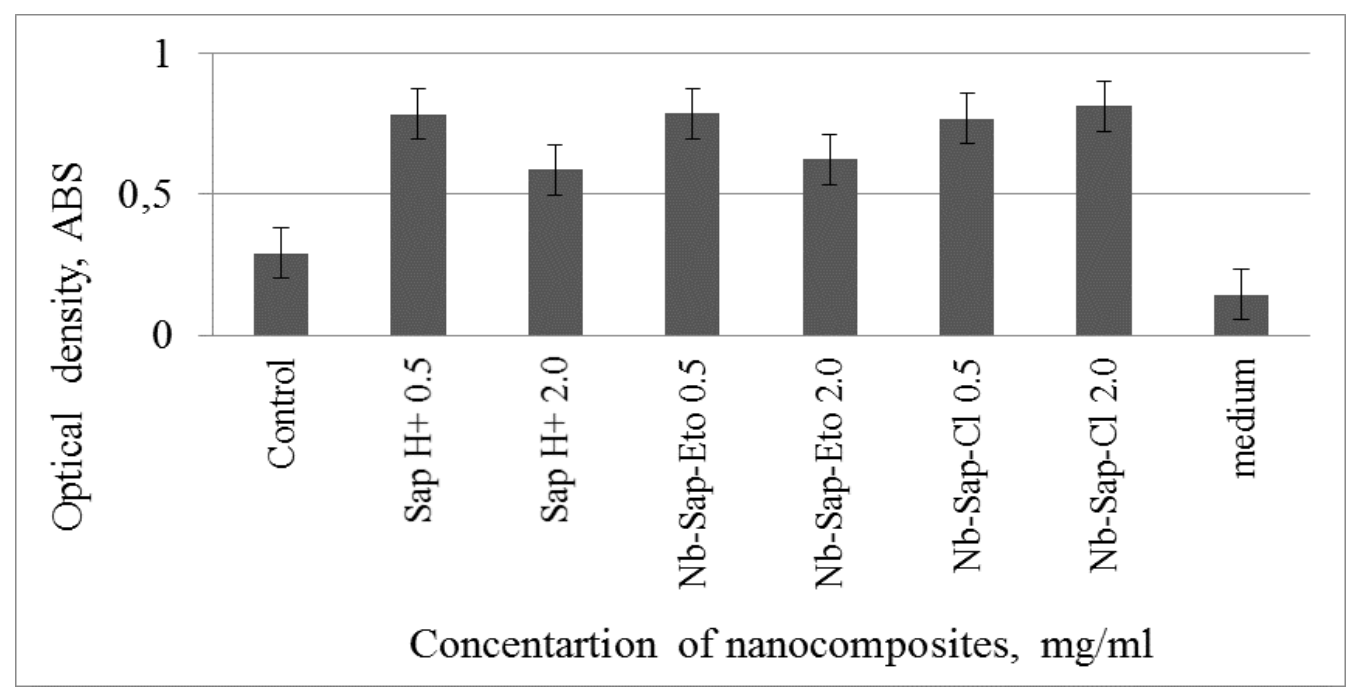

Pic. 3. Determination of the effect of the nanocomposites on the some biochemical properties of S. cerevisiae cells 
Conversely, in the presence of $\mathrm{Nb}-\mathrm{Sap}-\mathrm{Cl}$ at a concentration of $2,0 \mathrm{mg} \mathrm{ml}^{-1}$, it was as high as 0,8137 . Such behaviour can be attributed to the remarkable hydrolytic and acid properties of the tested saponite clays (either with or without niobium), which can stimulate the mitochondrial reductases in the yeast cells.

Conclusion. The effect of acidic and niobiumcontaining saponite clays on the cells in the culture of $S$. cerevisiae was studied and registered. The most effect has been observed in the presence of $\mathrm{Nb}$-Sap-EtO, a niobium-containing clay is prepared

\section{BIBLIOGRAPHY}

1. Accumulation of gold nanoparticles in Brassica juncea / [Marshall A. T., Haverkamp R. G., Davies C. E., Parsons J. G., Gardea-Torresdey J. L., van Agterveld D.] // Int. J. Phytoremed. - №9. - 2007. - P. 197-206.

2. Buzea C. Nanomaterials and nanoparticles: sources and toxicity / C. Buzea, I. Pacheco, K. Robbie // Biointerphases. - №2. - 2007. - MR17-MR172.

3. Cellular uptake of functionalized carbon nanotubes is independent of functional group and cell type / [Kostarelos K., Lacerda L., Pastorin G., Wu W., Wieckowski S., Luangsivilay J., Godefroy S., Pantarotto D., Briand J. P., Muller S., Prato M., Bianco A.] // Nature Nanotech. - №2. - 2007. P. 108-113.

4. Cellular responses to nanoparticles: target structures and mechanisms / [Unfried K., Albrecht C., Klotz L. O., Von Mikecz A., Grether-Beck S., Schins R. P. F.] // Nanotoxicol. - №1. - 2007. P. 52-71.

5. Clays Clay Miner / [Kloprogge J. T., Breukelaar J., Jansen J. B. H., Geus J. W.]. - №41. 1993. - $103 \mathrm{p}$.

6. Change of Extracellular Polymeric Substances Composition of Thiobacillus thioparus in Presence of Sulfur and Steel / [Boretska M., Bellenberg S., Moshynets O., Pokholenko I., Sand W. J.] // Microb. Biochem. Technol. - №5. - 2013. - P. 068-073.

7. Comparison of molecular and histological changes in zebrafish gills exposed to metallic nanoparticles / [Griffitt R. J., Hyndman K., Denslow N. D., Barber D. S.] // Toxicol. Sci. - №107. - 2009. P. 404-415.

8. Cytotoxicity of colloidal CdSe and $\mathrm{CdSe} / \mathrm{ZnS}$ nanoparticles / [Kirchner C., Liedl T., Kudera S., Pellegrino T., Javier A. M., Gaub H. E., Stolzle S., Fertig N., Parak W. J.] // Nano Letters. - №5. 2005. - P. 331-338.

9. Differential gene expression in Daphnia magna suggests distinct modes of action and bioavailability for $\mathrm{ZnO}$ nanoparticles and $\mathrm{Zn}$ ions / [Poynton H. C., Lazorchak J. M., Impellitteri C. A., Smith M. E., from niobium ethoxide, when at the concentration of $2 \mathrm{mg} \mathrm{ml}^{-1}$, when the number of cells increased by 5 times compared to the reference level in the control.

According to the MTT test with (3-(4,5dimethylthiazol-2-yl)-2,5-diphenyltetrazolium bromide), the most relevant effect, with respect to the control tests, was recorded in the presence of acidic H-Sap and the hydrolytically-active Nb-Sap-EtO sample at the concentration as low as $0,5 \mathrm{mg} \mathrm{ml}^{-1}$. They were able to stimulate the activity of mitochondrial reductases in yeast cells.

Rogers K., Patra M., Hammer K. A., Allen H. J., Vulpe C. D.] // Environ. Sci. Technol. - №45. 2011. - P. 762-768.

10. Direct imaging of single-walled carbon nanotubes in cells / [Porter A. E., Gass M., Muller K., Skepper J. N., Midgley P. A., Welland M.] // Nature Nanotech. - №2. - 2007. - P. 713-717.

11. Does carbon nanopowder threaten amphibian development? Carbon 50 / [Bacchetta R., Tremolada P., Di Benedetto C., Santo N., Fascio U., Chirico G., Colombo A., Camatini M., Mantecca P.]. - 2012. P. 4607-4618.

12. Ecotoxicity of nanoparticles of $\mathrm{CuO}$ and $\mathrm{ZnO}$ in natural water / [Blinova I., Ivask A., Heinlaan M., Mortimer M., Kahru A.] // Environ. Pollut. - №158. 2010. - P. 41-47.

13. Elder A. Physicochemical factors that affect metal and metal oxide nanoparticle passage across epithelial barriers / A. Elder, S. Vidyasagar, L. DeLouise // Wires Nanomed. Nanobio. - №1. 2009. - P. 434-450.

14. Environmental behavior and ecotoxicity of engineered nanoparticles to algae, plants, and fungi / [Navarro E., Baun A., Behra R., Hartmann N. B., Filser J., Miao A. J., Quigg A., Santschi P. H., Sigg L.] // Ecotoxicology. - №17. - 2008. - P. 372-386.

15. Exposure of engineered nanoparticles to human lung epithelial cells: influence of chemical composition and catalytic activity on oxidative stress / [Limbach L. K., Wick P., Manser P., Grass R. N., Bruinink A., Stark W. J.] // Environ. Sci. Technol. - №41. - 2007. - P. 4158-4163.

16. Genotoxicity investigations on nanomaterials: methods, preparation and characterization of test material, potential artifacts and limitations - Many questions, some answers / [Landsiedel R., Kapp M. D., Schulz M., Wiench K., Oesch F.] // Mutat. Res.Rev. Mutat. - №681. - 2009. - P. 241-258.

17. Induction of mesothelioma by a single intrascrotal administration of multi-wall carbon nanotube in intact male Fischer 344 rats. / 
[Sakamoto Y., Nakae D., Fukumori N., Tayama K., Maekawa A., Imai K., Hirose A., Nishimura T., Ohashi N., Ogata A.] // J. Toxicol. Sci. - №34. 2009. - P. 65-76.

18. Kashiwada S. Distribution of nanoparticles in the seethrough medaka (Oryzias latipes) / S. Kashiwada // Environ. Health Persp. - №114. 2006. - P. 1697-1702.

19. Langmuir 24 / [Bisio C., Gatti G., Boccaleri E., Marchese L., Bertinetti L., Coluccia S.]. - 2008. P. 2808-2819.

20. Liu W.T. Nanoparticles and their biological and environmental applications / W. T. Liu // Journal of Bioscience and Bioengineering. - №102. 2006. - P. 1-7.

21. Moore M.N. Do nanoparticles present ecotoxicological risks for the health of the aquatic environment / M. N. Moore // Environ. Int. - №32. 2006. - P. 967-976.

22. Mraz S. J. Nanowaste: the next big threat? / S. J. Mraz // Machine Design. - №77. - 2005. P. 46-53.

23. $\mathrm{Nb}(\mathrm{V})$-saponite clay for the catalytic oxidative abatement of chemical warfare agents / [Carniato F., Bisio C., Psaro R., Marchese L., Guidotti M.] // Angew. Chem. Int. Ed. - №53 (38). 2014. - P. 10095-10098.

24. Oberdorster $G$. Toxicology of nanoparticles: a historical perspective / Oberdorster G., Stone V., Donaldson K. // Nanotoxicology. - №1. - 2007. -
P. 2-25.

25. Provost J. MSU Moorhead Department of Chemistry [Electronic resource] / J. Provost // Summer Hockey. - 2012. - Protocols : http://web.mnstate.edu/provost/MTT\%20Proliferatio n\%20Assay\%20Protocol\%202012.pdf(19.05.2008).

26. Risk assessment of engineered nanomaterials and nanotechnologies - a review / [Savolainen K., Alenius H., Norppa H., Pylkkanen L., Tuomi T., Kasper G.] // Toxicology. - №269. - 2010. - P. 92104.

27. Surface-structure-regulated cell-membrane penetration by monolayer-protected nanoparticles / [Verma A., Uzun O., Hu Y., Hu Y., Han H. S., Watson N., Chen S., Irvine D. J., Stellacci F.] // Nature Mater. - №7. - 2008. - P. 588-595.

28. The effect of particle design on cellular internalization pathways / [Gratton S. E. A., Ropp P. A., Pohlhaus P. D., Luft J. C., Madden V. J., Napier M. E., DeSimone J. M.] // Proc. Nat. Acad. Sci. - №105. 2008. - P. 11613-11618.

29. Toxic effects and ultrastructural damages to Daphnia magna of two differently sized $\mathrm{ZnO}$ nanoparticles: Does size matter? [Electronic resource] / [Santo N., Fascio U., Torres F., Guazzoni N., Tremolada P., Bettinetti R., Mantecca P., Bacchetta R.]. Elsevier Ltd. - 2014. - Protocols : http://dx.doi.org/ 10.1016/ j.watres.2014.01. 